DE DE GRUYTER OPEN
Research Article

(C) 2018 Masnun.

This is an open access article licensed under the Creative Commons Attribution-NonCommercial-NoDerivs License (http://creativecommons.org/licenses/by-nc-nd/3.0/).

\title{
Blasphemy, the Fate of Ahmadiyya in Lombok and a Critique of Religious Discourse
}

\author{
Dr. Masnun, M.Ag. \\ Universitas Islam Negeri Mataram
}

Doi: $10.2478 / m j s s-2018-0077$

\begin{abstract}
Though Indonesia has claimed a principle of Bhinneka Tunggal lka ("different but one"), in reality the country has faced fragmentation over the differences in its society, with its people blaspheming and killing each other. Ironically, the inter-religious conflict which has occurred is no longer between practitioners of different religions, but between practitioners of the same religions. This article is based on observational research conducted by the writer during his time in an area which has faced relatively intense violence: Lombok. Observations indicate that several types of violence are occurring in this area, namely cultural violence, social violence, gender violence, and violence in the name of religion. This last type of violence has been particularly dominant in Lombok, which is popularly known as "the island of a thousand mosques". One form of violence in the name of religion is violence against the area's Ahmadiyya population. One may ask, then, why is violence still used and considered a superior approach to problem solving than non-violence? Why are people trapped in the logic of difference and forget that different peoples have meeting points? How can these differences be dealt with so that they do not become self-destructive forces?
\end{abstract}

Keywords: Blasphemy, Ahmadiyya, Sasak, Religious

\section{Introduction}

The indigenous people of Lombok are the Sasak. They are the majority ethnic group that represents $89 \%$ of the island's total population; the remainder consists of immigrant ethnic groups such as the Balinese, Sumbawa, Javanese, Arabs, and Chinese (Erni Budiwati, 2000). The Sasak are spread throughout Lombok, while the immigrant populations tend to settle in specific areas. Most of the Balinese people, for example, live in West Lombok and Central Lombok. The Sumbawa mostly live in East Lombok. The Arabs, meanwhile, tend to live in Ampenan, leading to the area being known as the Arab Kampung of Ampenan. Similarly, there is a Javanese settlement known as Kampung Jawa. The Chinese people, who generally work as traders, live in urban centers such as Cakranegara, Ampenan, and Praya.

The Sasak of Lombok are a religious people whose daily lives are steeped in a religious spirit. This, in turn, affects the way the community views its surrounding reality. Particularly important for the Sasak are Islamic teachings, which are used to run their daily religious lives in accordance with Islamic religious doctrines. The strength of the Islamic religious tradition can be seen by the number mosques on the island: 3,151 . It is therefore not surprising that Lombok has become known as Pulau Seribu Masjid ("the island of a thousand mosques"). The seriousness of the Sasak people's worship is likewise indicated by the annual increase in hajj pilgrims (Noor et al., 2004).

Islamic religious traditions in Sasak, since their introduction, have emphasized the strengthening of religious practices and rituals. Though this may appear at a glance to attach great importance to religious expression in the form of archetypal rituals, it has been transformed into 
particular patterns of worship with an emphasis on zhahir an-nas in the interpretation of Islamic teachings.

\subsection{Research Methode}

This study is a field research study using an approachment of Entnometodology. Subjects of this research are muslim leaders, public figures, grass root people, traditional leaders, researchers as well as students. These subjects were being interviewed. Data were collected from gaining and tracing informations from books, magazines, newspaper, and others supported documents.

\section{Islam and its Struggles in Lombok}

Islam has been and become a major force in Lombok society, as most of its population is Muslim. Almost all of the Sasak, the majority ethnic group, are Muslims, to the point that one ethnographer has even said that "to be Sasak means to be Muslim". Though this statement is not entirely true (as it ignores the popularity of Sasak Boda), ${ }^{1}$ similar sentiments are held by much of Lombok's population. Sasak identity is closely associated with a Muslim identity (Erni Budiwati, 2000). NonIslamic religions (Hinduism, Buddhism, and Christianity), meanwhile, are often associated with immigrant populations such as the Balinese and Chinese.

The Islamic practices in Lombok are not monolithic. Parts of the population belong to groups that claim to be modernist (such as Muhammadiyah and Persis), while others are part of traditionalist Islamic groups such as Nahdlatul Wathan (NW) ${ }^{2}$ and Nahdlatul Ulama (NU). ${ }^{3}$ Both types of practices can be found in West Lombok and East Lombok. ${ }^{4}$

Furthermore, several denominations can be found in Lombok. Practitioners can be classified, for instance, as members of the Wahabi congregation (Wahabiyah Jamaah) or as followers of the Qadiriyah and Naqsabandiyah tarekat (school of spiritual thinking). The former denomination of Islam is found most predominantly in East Lombok and has numerous followers. Most of the Wahabi congregation is from the lower and middle classes, which commonly includes indigenous farmers as well as some migrants from Java. The Wahabis also offer religious education and religious boarding schools (pesantren), with a focus on regional development, in Aikmel and Sulaga, East Lombok. Persons following the tarekat of Qadiriyah and Naqsabandiyah, meanwhile,

\footnotetext{
${ }^{1}$ Boda is the original belief system of the Sasak people before the arrival of foreign influences. The Sasak who adhere to this belief are termed Sasak Boda. This belief system is characterized by animism and pantheism. The veneration and worship of ancestral spirits and various other local deities are the main focus of religious practice of Sasak Boda. See Erni Budiwanti, "The Impact of Islam on the Religion of the Sasak in Bayan, West Lombok" in Kultur Volume I, No.2/2001/p. 30.

${ }^{2} N W$ is a social organization engaged in educational, social and Islamic da'wah (proselytization). This organization was founded by TGH. KH. Muhammad Zainuddin Abdul Madjid on 15 Jumadil Akhir 1372 H / 1 March 1953 AD in Pancor East Lombok, West Nusa Tenggara. See Abdul Hayyi Nu'man and Sahafari Asy'ari, Nahdlatul Wathan Organisai Pendidikan, Sosial dan Politik (East Lombok: NW Regional Board of East Lombok, n.d.), p. 84, and Mohammad Noor, et al., Visi Kebangsaan Religius: Refleksi Pemikiran dan Perjuangan Tuan Guru Kyai Haji Muhammad Zainuddin Abdul Madjid 1904-1997 (Jakarta: Logos Wacana Ilmu, 2004), p. 204. Read also Usman, Filsafat Pendidikan: Kajian Filosofi Pendidikan Nahdatul Wathan di Lombok (Yogyakarta: Teras, 2010).

${ }^{3}$ Discussion of the history and progress of NU in Lombok can be found in Taqiuddin A. Mansoor, NU Lombok: Sejarah Terbentuknya Nahdatul Ulama Nusa Tenggara Barat (West Nusa Tenggara: Pustaka Lombok, 2008) and Ida Bagus Putu Wijaya Kusuma, NU 1953-1984 Lombok (West Nusa Tenggara: Pustaka Lombok, 2010).

${ }^{4}$ Traditionalists have the tendency to "hold fast" onto old practices to maintain the purity of their heritage through maintaining old elements. It should be emphasized here that the Sunni "traditional" identity adopted by the NU and NW ulama is not intellectual conservatism, as is evidenced by the strong traditions of the Islamic world and Muslims' perseverance and steadfastness in the pursuit of knowledge; these traditionalists are students seeking knowledge. Here NU traditionalism must be distinguished from modern Islamic organizations such as Persis and Muhammadiyah, who firmly reject mazhab (schools of thought, or sects). Alignment with products which have been practiced from generation to generation is characteristic of NU and NW traditionalism, as is a strong tendency to maintain the existing establishment (status quo) and reject the new thoughts which challenge it.
} 
are often referred to as followers of orthodox or traditional Islam. Historically, the teaching of the Qadiriyah and Naqsabandiyah tarekat in Lombok began in the $19^{\text {th }}$ century, following the return of several master teachers from the al-Haram Mosque in Mecca. These khalifah ${ }^{5}$ were appointed by Sheikh Khatib Sambas. ${ }^{6}$

One of the most recent denominations to enter Lombok is Ahmadiyya, which presently only has a few hundred members. After the expulsion of Ahmadis from the villages of Bayan, Selong, Praya and Pancor, they can only be found in Ketapang Village and (dispersed) in the provincial capital of Mataram. This latter location is relatively more heterogeneous; Mataram is home to many Balinese Hindus as well Minahasa, Batak, Chinese, etc. Christians. West Lombok, where Mataram is located, has a tourism industry centered around Senggigi Beach; as such, it is relatively more open than the homogeneous Sasak Ahmadi village of Ketapang.

This description of the realities faced by Muslims in Lombok indicates that, throughout this island, Islamic teachings are varied. This has caused differences in the interpretation and practice of religion to emerge. The uneven spread of Islam and the preservation of local pre-Islamic beliefs have been deeply embedded in local structures and are suspected to be important factors in the different degrees in Islam's acceptance and understanding. Schwarz's statement that most Islamic communities in Indonesia consist of persons who think that Islam is just the latest addition to their mixed cultural traditions can be justified (Schwarz, 1994).

Differences in perspectives and understandings regarding the absorption and execution of Islamic teachings, as well as the religious accommodation of specific local structures, have contributed to the plurality of Islam in Indonesia. Soebardi describes Islam in the country thusly:

The Islamic reality of life is very pluralistic. One can find various ways of Muslims receiving and practicing Islamic teachings. Orthodox group practice religious obligations with full devotion. Meanwhile, many people call themselves Muslims but have a very shallow and imperfect understanding of and in their daily lives do not implement the instructions of their religion. It could be added here that many elements of worship come from the pre-Islamic era (Erni Budiwati, 2000).

\section{Dark History of Ahmadiyya in Lombok}

To understand the history and controversy surrounding Ahmadiyya in Indonesia, it is necessary to first examine the origins and teachings of Ahmadiyya itself. Ahmadiyya originated in India as a religious movement in the mid-1800s. In response to two Hindu religious reform movements in India, Mirza Ghulam Ahmad initiated a revival of Islam and Islamic missionary efforts. He began to disseminate his ideas through his publication of 'Proofs of Ahmadiyya' in 1880. This led to the establishment of the Ahmadiyya movement in 1889.

From the beginning, Ahmad declared Ahmadiyya to be an Islamic movement. His teachings differed, however, from the traditional Islamic doctrine in some important ways. The greatest offense to orthodox Islam was Ahmad 's claim that God's revelation did not cease with Prophet Muhammad, but that Ahmad himself was the spirit of the Prophet's incarnate or the Mahdi-the Messiah being many Muslims expected to come before the apocalypse to lead the faithful.

In Indonesia, violence against the Ahmadi has escalated since the presidency of Susilo Bambang Yudhoyono. The Majelis Ulama Indonesia (Indonesian Council of Islamic Scholars, henceforth MUI) fatwa of 1980 was ignored by the Suharto regime, and thus it was ineffective. Abdurrahman Wahid, during his presidency, greeted the Ahmadi high Islamic priest Mirza Tahir

\footnotetext{
${ }^{5}$ Khalifah is a term found in tarekat which refers to a student who has achieved a specific level in accordance with the normative measures of a sheikh (a spiritual teacher in tarekat). The khalifah then become an assistant to the sheikh during the process of transforming and conveying teachings. Three of the most prominent khalifah in Indonesia at the time were Sheikh Abdul Karim of Banten, Sheikh Ahmad bin Muhammad Hasbullah of Madura, and Sheikh Tolhah of Cirebon. Dadang Kahmad, Tarekat dalam Islam, Spiritualitas Masyarakat Modern (Bandung: Pustaka Setia, 2002), p. 100.

${ }^{6}$ Shaykh Khatib Sambas was a highly respected ulama of his time and a role model to students (seekers of knowledge) particularly those from the Indonesian archipelago. He came from Sambas, West Kalimantan, and stayed in Mecca until he died there about 1878. Martin Van Bruinessen, Tareqat Naqsabandiyah di Indonesia: Survei Historis, Geografisdan Sosiologis (Bandung: Mizan, 1992), p. 91.
} 
Ahmad, the grandson of Mirza Ghulam Ahmad, in Jakarta. Similarly, when Megawati ruled over Indonesia, there was no policy forbidding Ahmadiyya. This all changed in 2005, when the MUI issued a fatwa on Ahmadiyya ${ }^{7}$ and the government accommodated it through three ministerial decrees in 2008 Ahmadiyya.

Though violence against Ahmadis has escalated, it is not new in Indonesia. The Ahmadis, both adults and children (including orphans), have experienced various forms of mistreatment. The state and general populace, meanwhile, seem to simply act as bystanders. They do not take action to crack down on perpetrators or treat perpetrators as enemies of the state (as they do with terrorists).

Violence against the Ahmadis in Lombok can be seen as early as 1999 in Bayan, West Lombok, when one person was hacked to death, while another was grievously wounded. In 2001 there was a similar incident in Pancor, East Lombok. expulsion from their homes. Oddly, in response the local government of East Lombok gave the Ahmadis two options: they could leave Ahmadiyya and remain in Pancor, or they could remain in Ahmadiyya but leave the village. It is ironic that such persecution and eviction occurred in a nation which, people say, promotes and upholds diversity and human rights.

Violence against the Ahmadi has continued. To respond to this violence, in August 2005, during a period of frequent anti-Ahmadi demonstrations and fevered discourse, the writer delivered a lecture at the Tabligh Akbar ('great meeting') at the Jami' Mosque of the Regency on behalf of a committee which called itself the Aliansi Masyarakat Anti-Ahmadiyah (Anti-Ahmadiyya Alliance). From the proposal for this lecture, it was clear that the committee speakers and the masses to condemn the region's Ahmadis. The writer, however, refused to do so. Instead the writer offered theological and sociological explanations, reciting verses of the Qur'an which explained freedom of religion and that coercion (or even violence) to promote conversion was not allowed in Islam. The writer then provided examples from two prominent Lombok figures' interactions with the Ahmadi, specifically al-Magfurlahu TGH. M. Zainuddin Abdul Madjid (the Founder of NW) and TGH. M. Faisal (the NU leader in Lombok). Neither of these figures had, to the writer's knowledge, issued a fatwa condemning the Ahmadi as misguided, let alone invited and mobilized people to attack them. This could be seen from the Ahmadiyya Mosque on Sudirman Street, Pancor, not far from the secretariat office of PBNW. Similarly, in Praya, where many members of TGH. Faisal's congregation lived, Ahmadis still had freedom of worship.

The writer has observed that many Ahmadis have, as a result of violence against them, lost their homes, livelihoods, and the peace that they had enjoyed. Their children can no longer attend school, and their wives are no longer free to go to public places such as markets. The Ahmadis have become frightened and ashamed.

They have faced a corruption of the purpose of religion. Religion is supposed to be a protector, a provider of security, a spreader of peace on Earth, but has been repurposed to light the flame of hatred and hostility among the devout. Why, however, have religious leaders sometimes failed to develop a sense of sincerity among their followers? Writing in the late $19^{\text {th }}$ century, Friedrich Nietzsche-one of the most prominent reformers of theological philosophy- saw a terrible reality in the so-called "religion" of his time. The dissemination of hatred through the media and the fighting of wars was frequently initiated by religious organization. Religion, he held, was not presented as a humanist doctrine which respects human life. Nietzsche concluded that specific historical consciousnesses had become ensconced in religion and believed by millions of people. Religion had become corrupted. Nietzsche's most popular phrase, Gott ist tot, "God is dead", have been used when interpreting religion's role in exploitation, the Holocaust, and misogyny.

If probed further, the violence against the Ahmadis is a realization of State defeat. The State

\footnotetext{
${ }^{7}$ This was not the first MUI fatwa on Ahmadiyya. In 1984, MUI issued a similar fatwa. The writer holds that the case of Ahmadiyya is a contestation over claims of truth; such contestation between different thoughts (textual conservatism and innovativism, Arabic and non-Arabic culture, and between different denominations of Islam) have been common throughout history. What is needed here is criticism of religious discourse and understanding, rather than religion as a whole. See M. Atho Mudzhar, Fatwa-fatwa, p. 134. For the latest fatwa from MUI on Ahmadiyya, see Nana RI Iskandar, Fatwa MUI dan Gerakan Ahmadiyya Indonesia (Jakarta: Darul Islamiah Kutbil GAl, 2005)
} 
can be considered inexistent as it is unable to enforce the laws which citizens are breaking, instead choosing to simply "apologize". Furthermore, the State appears to have relented completely to the pressures of particular groups. It is unable to take a firm stance against the groups that commit such acts of violence.

Rather, it has seemed to support them. The violence against the Ahmadis of West Nusa Tenggara pushed the local government to issue such legislation as: 1) Decree of the Regent of West Lombok No.35 of 2001 on the Prohibition and Cessation of Ahmadi Doctrine/ldeology in West Lombok Regency, a decree which is based on Recommendation of the MUI of West Lombok Regent Number 12/MUI-LB/7/2001 (dated 5 July 2001), which contains a request that the Government of West Lombok "explicitly prohibit the activities of this group and also firmly crack down on any violations of the prohibition"; (2) Decree of the Regent of East Lombok No. 045.2/134/KUM/2002 of 13 September 2002, which prohibits the dissemination of Ahmadiyya teachings and ideology, both oral and written, in East Lombok; 3) Letter of the West Nusa Tenggara Governor No. KW.19.1/4/HU.00/1353/2006, dated 28 March 2006 and addressed to the Minister of Home Affairs, Minister of Religious Affairs, and the Attorney General; this letter requested the prohibition of Ahmadiyya in West Nusa Tenggara.

Today, the Ahmadis take shelter in the Transito Dormitory in Mataram. In an interview, one Ahmadi said:

We have been forced to stay in this dormitory. We do not dare return to the village. We are afraid that the burning will begin again. We are surprised that our brothers hate us so much, even though we worship as stipulated in Islamic teachings. They assume that we are sesato (animals). Why, even after Independence, can we not enjoy this freedom, when during the revolution we fought together without any concern for our denomination or beliefs. Hopefully this is a trial, one through which we must remain steadfast in our worship, and the government is willing to resolve this problem, because we regret that our children dare not go too far from this place. ${ }^{8}$

The continued existence of problems between the Ahmadis and the surrounding society in their social interactions can be seen from society's treatment of them. As recognized by Hidir, the Ahmadis feel as though they are treated differently, as do their children, who study at an elementary school near the Transito Dormitory. Though social interactions have improved recently, the discrimination is nonetheless clearly felt. For example, the children receive their school reports collectively in the form of a single sheet captioned "the learning results of Ahmadi children". ${ }^{9}$

The writer's field observations at Transito Dormitory suggest that the conditions of the Ahmadi families' residence have limited their personal activities. For more than a year, they lacked water and light because the national water and electric companies had cut off service; the manager of the dormitory did not want to pay the bills. Their present residence appears to actually be more like "an isolation camp" intended to continually pressure Ahmadis until they "give up and repent" by abandoning their beliefs. In other words, even today there is an intention to force the Ahmadis to stay in such deplorable conditions. Their refusal to "acknowledge their deviation" and "return to Islam" has been considered an act of defiance which rejects the solution offered by the government. ${ }^{10}$ This can be seen in the utterances of government officials. For example, the Director General for the Societal Protection and Police for West Nusa Tenggara stated that the Ahmadis "... do not want to be taken care of, and the government does not want to take care of them". Similar sentiments were expressed by the Head of Public Relations of the Regional Office of the Ministry of Religious Affairs for West Nusa Tenggara: "The government has not given up in taking care of them, but they (the Ahmadis) do not want to listen to the government". ${ }^{11}$ The MUI chapter in West Nusa Tenggara, meanwhile, considers the Ahmadiyya issue "already finished" with their decree, as "we do not need dialogue and talks because we have obviously based [our decree] on the MUI

\footnotetext{
${ }^{8}$ Interview with Hidir at the Transito Dormitory in Mataram, 3 January 2008.

${ }^{9}$ Interview with Hidir at the Transito Dormitory in Mataram, 3 January 2008.

10 Observation, 3 January 2008.

${ }^{11}$ Lombok Post, 29 October 2009.
} 
fatwa. Communication between the MUI and the Ahmadis is finished". ${ }^{12}$

The MUI fatwa which declared Ahmadiyya to be heretic in 1980 may serve as reflection of the "breakdown" of inter-religious harmony which is characterized by increased conservatism in religious life. It is thus unsurprising that the 1980 fatwa was released almost in conjunction with the MUI fatwa which declared that saying "Merry Christmas" was haram (forbidden). The 2005 MUI fatwa was born of a similar context. At that time, the Ahmadis were often depicted as a common enemy by conservative groups in religious organizations, including both those known for their violence and more moderate ones such as NU and Muhammadiyah. These groups were united to face the common enemy and thus collaborated in issuing the 2005 fatwa.

This could explain, at least partially, why the $2005 \mathrm{MUI}$ fatwa confirming the $1980 \mathrm{MUI}$ fatwa that declared Ahmadiyya to be haram was issued in conjunction with fatwa denouncing pluralism, liberalism and secularism. The Ahmadis and pluralist groups were both considered common enemies, and as such the "alliance" of conservative Islamic groups, considering the $1980 \mathrm{MUI}$ fatwa to be ineffective, felt a need to reaffirm MUIS's stance on Ahmadiyya. In fact, even after the issuing of the $1980 \mathrm{MUI}$ fatwa, the number of Ahmadis grew, and more of them propagated their beliefs publicly, especially during the Reform period; ironically, similar trends in preaching have been practiced by the conservatives.

Judging from above trend, there is a greater possibility that the Ahmadi in Indonesia will be forced to undergo the same fate as the Ahmadi in other Islamic and majority Muslim countries. Moreover, various political forces in Indonesia tend to take a "safe approach" to the "Ahmadiyya problem", and as such they do not adopt a proper attitude. If they are considered to support Ahmadiyya and the Ahmadis, they will likely lose the support of the majority of Indonesian Muslims, who tend to be anti-Ahmadiyya.

The Ahmadis in Lombok share similar experiences to other denominations which are considered to deviate from mainstream Islam, such as the Wetu Telu Muslims, who can also be found in Lombok. As a minority, the Wetu Telu have been pressured both directly and indirectly by three layers of "oppression": the penetration of modernity, the incessant dissemination of mainstream Islamic da'wah, and the massive implications of political policies-particularly the transmigration program. The Wetu Telu remaining in Lombok have become increasingly distant from the general Sasak community and stigmatized as being "out of date" and theologically "misguided"; therefore, it is commonly held that they need to receive da'wah. Is it true that the teachings of the Wetu Telu are misguided according to figh and theology? Why are local nuances of Islamic beliefs always marginalized? Is this not a proof of religious plurality within Islam itself, which shows the religion's hospitality towards local cultures? The conversion of the Sasaks from Boda (Hindu-Buddhist syncretism) to Islam, and the conversion of syncretic and nominal Muslims - called Wetu Telu—to the "perfect" Islam—referred to as Waktu Lima (Five Times, referring to the number of mandatory prayers) - shows the cultural dynamism through which Islam is spread, absorbed, accommodated, and expressed in Indonesia. This dynamism also underlies the fact that the dissemination and teaching of Islamic doctrine is a long and continuous process involving relentless antagonism and assimilation.

\section{Towards a Transormative Religious Understanding}

For the writer, the case of the Ahmadi in Lombok is a struggle over truth claims similar to those found throughout history among the textualists and interpretationists, the conservatives and innovatives, the Arabic and non-Arabic, and between different denominations of Islam. The issue requires a critique of religious discourse as well as a complete understanding, rather than a single

\footnotetext{
${ }^{12}$ Interview with Prof. Drs. H. Saiful Muslim in Mataram, 1 November 2009. Legislation on the Ahmadis includes Decree of the Minister of Religious Affairs No. 3 of 2008, Decree of the Attorney General No. Kep0333/A/JA/6/2008, and Decree of the Minister of Internal Affairs No. 199 of 2008. This latter legislation contains six warnings and commands targeted at followers, members and / or board members of both Ahmadiyya Jamaah in Indonesia (JAl) and the Ahmadi community. See http://www.kompas.com/read/xml/2008/06/09, accessed 2 May 2009.
} 
discourse of religion.

Non-singularity in understanding religious practices can be seen in the encounter of various historical religious traditions through inter-religious practices. In this global world, it is undeniable that religious practitioners attempt to formulate new concepts of morality. First, the internal moral issues of each religion have objective legitimacy pertaining to its beliefs, as related to an unavoidable and exclusive entity. Second, religions and their formulation seek a minimum framework for acting together to face challenges and anxiety. Third, religions are fully responsible for becoming involved in a global pool of plurality. This is, of course, one way to process religious challenges and can be adapted to historical laws which ensure differences. Religious practitioners must not so arrogant as to proclaim others to be infidels or deviants; they could be more noble and more religious (Islamic, in this case), in the presence of God (kufrun indan nass wa lakin mukmin indallah). A servant's accountability to God cannot be determined, generalized, or claimed by others, because there is no objective value which can be used as a parameter. Someone's faith (or lack thereof) in his or her beliefs cannot be judged by other humans (Hidayat, K, 1998).

Understanding, here, should be directed towards a fresher direction in which religion only sets the value system and ethical awareness of its followers. Religion should be seen as doctrine in which messages are encoded to improve the quality of human culture, rather than as formaltraditional ritual actions, as once expressed by Weber. The deepest element in religion is faith. It is faith that makes someone strong, consistent, and have high moral standard. Faith and morality are two related aspects, also called the effect of faith, of building a new awareness of faith within communities. Faith must become something sacred and undisputed. ${ }^{13}$

The MUI has refused to accept such a view. As stated above, the organization has issued two fatwas which declared that Ahmadiyya was heretic and urged Ahmadis to return to the purity of Islam or to form a new religion. These fatwa, issued in 1984 and on 29 July 2005, essentially held that Ahmadiyya as a belief system should be removed from Islam and proclaimed that its followers were misguided and misled. This fatwa has been used as justification for groups of people to label the Ahmadis as misguided people and even to expel them and raze their homes and places of worship. The claim that they are "deviant" has limited the options available to Ahmadis: they may either change their beliefs to match those of mainstream Islam or leave Islam and establish their own religion. Such theological logics and cliché solutions are routinely promoted by the ulama (Islamic scholars), particularly those united in $\mathrm{MUI}$, and then maintained by local and national authorities. For the writer, however, the true value of each belief is equal. One belief cannot be used as a yardstick against which the other belief's true value is measured, even when the first belief is embraced in majority. Based on epistemology, a belief is no more than a result of understanding, the ijtihadi product of thought, an interpretation of the fundamental doctrine.

Dealing with followers of other denominations or mazhab, a religious person must be prepared to face the fundamental differences and acknowledge them as life views regarding how one should think, behave, act and live. As Franscesco de Sanctis said, religious people should be cultured. Those who believe in God should also seek political order, a non-violence (ahimsa), clean government, and good governance, and aspire to democracy.

As such, responding to the plurality of religious beliefs with violence, as in the case of Ahmadiyya in Lombok is not a wise choice. Moreover, it goes against the basic message of Islam itself as a spreader of love and mercy (rahmatan lil alamin). If Ahmadi theological beliefs must still

\footnotetext{
${ }^{13}$ Weber defined mature religions as religions which can utilize rational thinking instruments more prominently than immature superstitions or rituals, which in many ways cannot be understood by more advanced global ethics. In this regard, Weber finds the ideal type of religion as a rational instrument to be Protestantism, which he attributes with creating the competitiveness of capitalism through its religious belief that faith is determined by how hard one develops one's own economic life and community. Many of his concepts link morality, faith, and culture. In the history of the moral reformation in Italy, for example, an understanding which criticized the strong construct of religious belief (by the Catholic Church) and its influence on secular thought and culture was intensively and initiated into idiomatic framework. Gramsci even concluded, by looking at the pollution produced by the church, that if there are moral and cultural presuppositions on one hand and religion on the other hand, it is religion that must be eliminated. An ethical society is most important. See St. Sunardi, Sastra dan Perkembangan Budaya (Yogyakarta: Sanata Dharma University Press, 2001).
} 
be viewed as "wrong" or "misguided", it is best to practice da'wah without violence, be it physical or non-physical. Da'wah should be delivered through wisdom and sagacity. Even the Prophet discussed with Christians, and Nazran said, "Let use discuss, talk to each other. Who knows, there is truth in us or in you".

In the Qur'an, God offers at least three options for a methodology to draw people to the truth. These are (1) describing wisdom (al-hikmah); (2) setting forth guidance or good advice (al-ma'izah al-hasanah); and (3) establishing dialogue (mujadalah). All of these must be conducted in a sympathetic manner (ahsan), with gentleness, without force, as reflected in the use of the words "invite" or "summon" at the beginning of verses. ${ }^{14}$ There is no indication to use violence, either explicit or implicit— such as the use of the terms "force", "assault", "destroy", or "kill"-in other verse.

\section{Continued Transformation Plan}

\subsection{Deconstruction of Fiqh Discourse}

The issue of relationship with non-Muslims, regardless of their religion and faith, is the most serious and dilemmatic problem in Islamic figh (jurisprudence). At this level, fiqh experiences an extraordinary weakness. The universality and flexibility of fiqh appear as if they are hidden, or even lost. Fiqh has been used, implicitly or explicitly, to spread hatred and distrust against other religions.

Several groups have always been viewed negatively according to classical fiqh, namely "polytheists", "apostates" and "infidels". ${ }^{15}$ When one versed in fiqh meets such a community, that person will often give this group a stern warning. The question then is, why is the character of classical fiqh like that? How is figh reconstructed in regards to inter-religious relationships? How does fiqh respond to minority rights? How does fiqh respond to violence in the name of religion? How does fiqh respond to the concept of citizenship?

Answering these questions requires a renewal and deconstruction of fiqh, particularly in restoring the inter-religious relations which have been tarnished over many years. Fiqh must be renewed at (at least) three levels. First, at the methodological level, there are many similarities to the renewals performed by other ulama versed in figh, including the need for contextual interpretation of figh texts, methodological schools, and verification between principal teachings and branches. At this level, at least two steps of deconstruction and reconstruction are required to promote the view that classical figh should be read in the context and spirit of the time.

Second, there must be a renewal at the ethical level. Fiqh, as a treasure which has grown among society, seems to provide a raw and ready to serve material. Consequently, the products of fiqh are formalistic and legalistic. A renewal of figh which understands said jurisprudence as social ethics is required.

Third, there must be a renewal at the philosophical level. Fiqh is actually open to philosophy and contemporary theories, especially in dealing with a multi-cultural and multi-religious society. It is important that fiqh can comprehensively take pictures of social reality. The most appropriate example for this case is human rights. To make fiqh interact with contemporary issues, it must "open up" and become progressive while simultaneously understanding concepts in a fundamental-rather than partial-manner. Of course, how figh can be open and progressive depends greatly one understanding of pluralist theology, because figh's emphasis on the rejection of other groups or communities is indeed the product of an exclusive theology.

\footnotetext{
${ }^{14}$ Q.S. an-Nahl [16]: 125

${ }^{15}$ Historical realities have colored the meaning of religious texts regarding religious rights, including the categorization of persons as Muslims or zimmi or harbi non-believers (dar al-Islam or dar al-kufr), as well as the identification, trial, and execution of apostates. Fiqh riddah, in classical Islamic jurisprudence, has frequently been used in discourse as the basis for urgent handling violence against Islam and the thoughts of the Muslim people. Faqihuddin Abdul Kadir, "Nilai-nilai Pluralisme dalam Ajaran Sosial Islam, Perspektif Fiqih Realitas", Ulumuna Volume VIII, Number 14, July to December 2004, p. 267.
} 


\subsection{Neutrality and Impartiality of State}

The constitutional guarantee of religious and principled freedom is actually the logical continuation and ontological recognition of the fact of social and cultural pluralism, including religious pluralism, which has existed in Indonesia for hundreds of years. The Republic of Indonesia was founded on such principles of pluralism. According to these principles, the state must be neutral and impartial in the case of internal disputes between-and within—religious communities.

\subsection{Tolerance in a Plural Society}

Religious belief-which is essentially individual-personal-must be guaranteed by democratic institutions for the implementation of social and political stability. This means that tolerance should be the norm for inter-religious and inter-faith relationships, with the state acting to protect the freedom of religious believers at the individual and group levels. In a pluralistic religious society, religious tolerance is a requirement which, above all things, must be maintained by the State as a constitutional mandate.

\subsection{Objectification of Religion through Deliberation}

Religious belief cannot simply be used as the basis for making or legitimizing public decisions unless it is first translated into secular political reason. This principle reminds us of what Kuntowijoyo termed the objectification of religion, that is, the transforming of a particular religion's norms and subjective values into universal social ethics so that they may be generally acceptable and applicable by all people through public deliberation.

Unfortunately, facts have shown that these three premises have collapsed in Indonesia in the face of rampant and incessant fundamentalist intolerance over the past ten years. Claims of exclusivity, which are particular and subjective, have even been used as reasoning to underscore actual coercive action through the State monopoly. Such reasoning has even infiltrated clerical institutions with semi-state agency status in the making of official fatwas, as in the case of antipluralism. In the case of Ahmadiyya, even the Minister of Religion has drafted a decree coercing Ahmadis to either change their religion or remove themselves from Islam.

Coming to this, it is unclear how fundamentalist reasoning has become so hegemonic, and thus how Indonesians-especially mainstream Muslims-should behave. Nurcholish Madjid's teachings that asked Muslims, as citizens, to impose a double attitude, one of "external pluralism and internal relativism," have been abandoned, and are no longer honored.

\section{Conclusion}

In an inspirational and normative way, Muslims have a source which is never dry through which they can look at the future. The Qur'an, as the container for a divine message, is eternal and always actual. The Qur'an is always present among its people, reaching beyond the limits of space and time. Its presence is always greeted with dialogue and comprehended interpretations and holy activities meant to capture its substantive messages. As such, although the revelation has textually expired, it has been and continues to be published. Furthermore, millions of works of interpretation have been and will always be produced by Muslims and non-Muslims alike. It seems as though no texts but the Qur'an has become the object of continued interrogation, dialogue, or consultation with such significant implications for society, politics, economics, and civilization. For Muslims, such themes as human rights, justice, egalitarianism, environmental protection, work ethos, and gender issues-all themes of humanity - have been part of the Qur'an and Islam from the beginning. The meaning of this divine revelation is treated as both a command and a way of life by believers (the mukmin), and this has encouraged the birth of an Islamic community (the ummah) and the institution of religious culture. In other words, religion is not only an individual belief, but also, from a socio-historical perspective, a home and cultural identity which offers protection as well as a curriculum for and meaning of life. 
For the future, it seems that there is no choice but to open up to dialogue and be ready to accept 'good things from other people.' Unfortunately, such dialogue will be nothing but beautiful yet empty words if it is insincere. Though religious leaders engage in close dialogue, those who follow them may continue to maintain suspicion. This is not entirely their fault; it is also the fault of those who do not disseminate the results of dialogue among the common populace. Moreover, if it is agreed that dialogue must be held by groups which are equal to each other, other problems will surface.

\section{References}

Abdul Hayyi Nu'man and Sahafari Asy'ari. Nahdlatul Wathan Organisai Pendidikan, Sosial dan Politik. East Lombok: NW Regional Board of East Lombok, n.d.

Dadang Kahmad, (2002). Tarekat dalam Islam, Spiritualitas Masyarakat Modern. Bandung: Pustaka Setia.

Budiwanti, E. (2001). The Impact of Islam on the Religion of the Sasak in Bayan, West Lombok. Kultur, Volume I, No.2.

Budiwanti, E. (2000). Islam Sasak : Wetu Telu Versus Waktu Lima. Yogyakarta: LKIS.

Hidayat, K. (1998). Agama-agama Besar Dunia: Masalah Perkembangan dan Interaksi. In Kamaruddin Hidayat and Ahmad Gaus AF (eds.). Passing Over: Melintasi Batas Agama (p. 201). Jakarta: Gramedia.

Kusuma, I.B.P.W. (2010). NU 1953-1984 Lombok. West Nusa Tenggara: Pustaka Lombok.

Madjid, N et al. (2004). Fiqih Lintas Agama. Jakarta: Paramadina.

Martin Van Bruinessen. (1992). Tareqat Naqsabandiyah di Indonesia: Survei Historis, Geografis dan Sosiologis. Bandung: Mizan.

Nana RI Iskandar. (2005). Fatwa MUI dan Gerakan Ahmadiyya Indonesia. Jakarta: Darul Islamiah Kutbil GAI.

Noor, M., Habib, M., Zuhdi, H.M. (2004). Visi Kebangsaan Religius; Refleksi Pemikiran dan Perjuangan Tuan Guru Kyai Haji Muhammad Zainuddin Abdul Madjid 1904-1997. Jakarta: Logos Wacana Ilmu.

Madjid, N et al., (2004). Fiqih Lintas Agama. Jakarta: Paramadina.

Schwarz. (1994). A Nation In Waiting: Indonesia in the 1990s. San Francisco: Westview, 163.

St. Sunardi. (2001). Sastra dan Perkembangan Budaya. Yogyakarta: Sanata Dharma University Press.

Taqiuddin A. Mansoor. (2008). NU Lombok: Sejarah Terbentuknya Nahdatul Ulama Nusa Tenggara Barat, West Nusa Tenggara: Pustaka Lombok.

Usman. (2010). Filsafat Pendidikan: Kajian Filosofi Pendidikan Nahdatul Wathan di Lombok. Yogyakarta: Teras. 